\title{
Earthquake - Science in Himalayas: Ground Water Quality Change and its Implications
}

\author{
Sushant Banjara ${ }^{1}$, Shukra Raj Paudel ${ }^{2 *}$ \\ ${ }^{1}$ Department of Civil Engineering, Kantipur City College, Purbanchal University, Kathmandu, Nepal \\ ${ }^{2}$ Department of Civil Engineering, Pulchowk Campus, Institute of Engineering \\ Tribhuvan University Pulchowk, Lalitpur, Nepal \\ *Corresponding author: srpaudel@ioe.edu.np
}

Received: Feb 22, 2017 Revised: March 16, $2017 \quad$ Accepted: May 20, 2017

\begin{abstract}
In this paper, we discuss the pre-earthquake and post-earthquake groundwater scenario in context of Nepal. Nepal being one of the most earthquake vulnerable countries, the implications of earthquake in Nepal is considerable. Study requires not so only above the earth surface, but also in sub-surface conditions. Of various geo-physical and geo-chemical, subsurface conditions, this particular study concerns with groundwater chemical parameters. Before the occurrence of earthquake, groundwater chemistry has been found to change in numerous instances as promising precursor of earthquake. On the other hand, the chemical changes in groundwater have been found to continue beyond the occurrence of earthquake. Some of these changes, due to their toxic nature, are likely to cause health hazards to people who directly consume groundwater. In this premise, we deduce that constant observation of groundwater chemistry before and after earthquake is crucial for both earthquake prediction science and for monitoring health risks that may arise from consuming chemically altered groundwater due to tectonic activity.
\end{abstract}

Key words: Earthquake precursors, earthquake prediction, Eurasian plate boundary, health hazards

\section{Introduction}

In 2015 April 25, Nepal became the centre of attention to the International community after a devastating earthquake of 7.8 magnitude in Richter-scale hit the country. International Media, foreign rescue forces, medical teams and everyone remotely concerned quickly directed their assist towards Nepal. Gorkha Earthquake 2015 alone killed nearly nine thousand people and caused economic loss equivalent to seven billion dollars [9]. Not only was the earthquake large in magnitude but also its origin was very close to Kathmandu Valley [1]: the most densely populated region as well as the cultural hub of the country. The region suffered considerable loss of life and property and also lost numerous cultural monuments - many of which were part of UNESCO World Heritage Sites [13].

The earthquake and resulting devastation was an event; everyone knew would happen sooner or later because Nepal completely lies in one of the most seismically active zones in the world and 
hence, has suffered several such earthquakes in the past as well. The frequency of occurrence of earthquake in Eurasian Plate Boundary Region (where Nepal lies) is fairly high and can be verified from the Fig.1 extracted from United States Geological Survey (USGS) website. Not only Nepal but the Himalaya Range as a whole is a high seismic-risk zone. Only in last hundred years The Himalayas endured more than 10 earthquakes of magnitude greater than 7 in Richter scale, 4 of which originated within the small territory of Nepal [8]. Subduction of Indian Plate into Eurasian Plate - the very reason that formed Himalayas - has created extreme geological instability in this region for over 50 million years, which results in frequent earthquakes of varying magnitudes. Major part of Himalayas lies in Nepal and hence, Nepal is one of the most earthquake prone countries and Kathmandu, the most earthquake vulnerable capital in the world. Recent GorkhaEarthquake and still-active series of aftershock is a prominent example of it.

The earthquake and its aftermath garnered huge attention from around the world. However, the amount of interest in the scientific aspect of the earthquake seems very unsatisfactory compared to the interest in socio-economic and cultural aspects of it. Due to highly unstable geology and resultant frequent earthquakes, this region perhaps has a lot to tell us about pre and post earthquake geological changes and its possible consequences. And, this is high time we started to look for obscurities of earthquakes beneath the soil of Himalayas. The overarching goal of the paper is to discuss the possibility of short term earthquake prediction and potential health hazards due to earthquake.

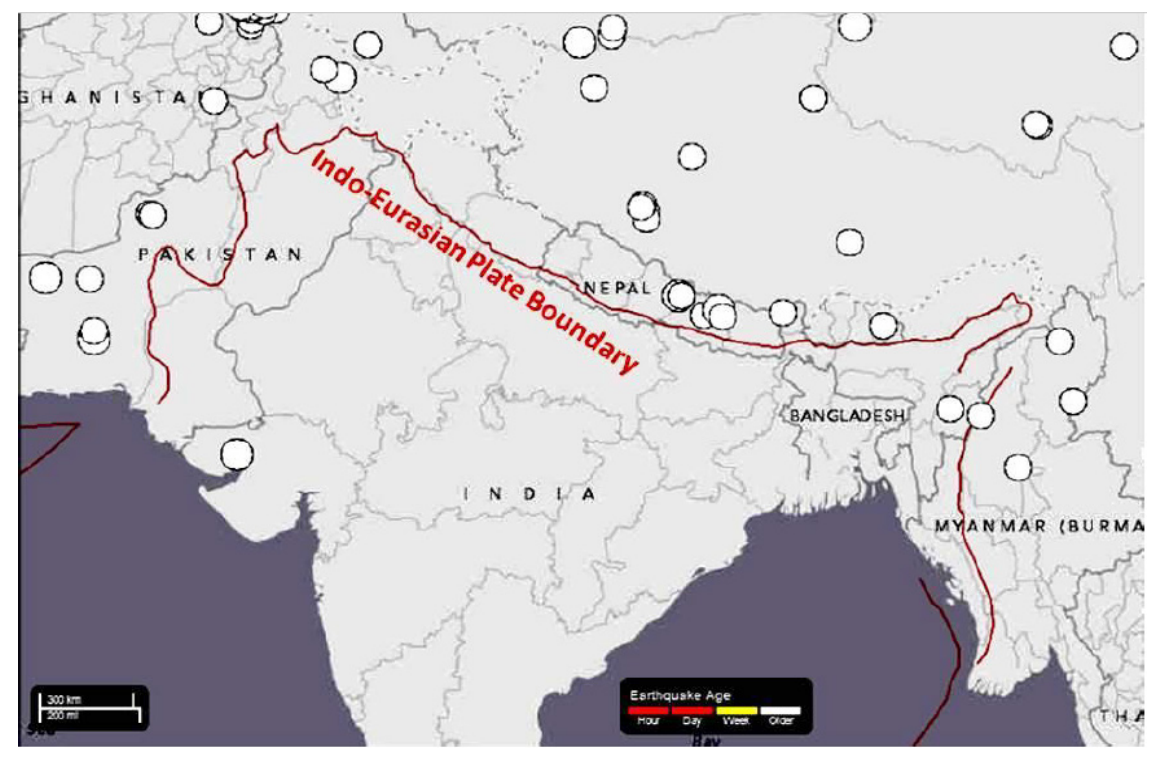

Fig.1: Earthquakes of magnitude 6+ (inclusive) occurred from 2000 to 2016 in the vicinity of Indo-Eurasian Plate Boundary

\section{Discussion}

As far as questions related to earthquake prediction are concerned, ground water has lots of answers. So far, scientists have been able to find changes in several water quality parameters associated with earthquake. These changes have been observed both before and after the occurrence of earthquakes. Some of these chemical changes are subtle while others are more prominent and conspicuous. Changes in water quality parameters after earthquake have been widely studied and 
well understood by scientists. However, changes in water quality parameters as a precursor to earthquake hasn't been sufficiently studied and lacks enough data to make any firm claims.

Himalayas as a high seismic-risk zone carries a great significance in earthquake-related researches, especially the ones related to water quality changes. These changes when occurred before the occurrence of earthquake can hint an impending disaster, i.e. the changes act as precursory phenomena. Moreover, the same changes can also pose threat to human and other living beings who consume the water. As a key to earthquake prediction as well as a threat to human health, groundwater conditions (chemistry) in Nepal in regards to earthquake is to be taken seriously and the same has been discussed below.

\subsection{Possibility of Short-term Earthquake Prediction}

Earthquake is one such natural disaster which every one wish could be predicted but even modern science and technology fails to do so with significant accuracy, as of now. However, in the past three decades several researches has been carried out and the results have indicated that changes in chemistry of water carries a clue to predictability of earthquakes. Different researches have used different parameters to check the chemical changes in water such as ion concentrations [12], stable isotope ratio [11], radon count rates [6], $\mathrm{pH}$ [7], and electrical conductivity. Some of these parameters changes several months before earthquake occurs. Anomalies in groundwater quality have been observed four to six months prior to two earthquakes of 5+ magnitudes [11]. Although, these parameters have shown possibility of prediction of earthquake, scientists, on the other hand agree that the data they have obtained are insufficient to establish any claims.

A long term data is required to establish any correlation between water quality and upcoming earthquake; this is exactly where Nepal fits in. Frequently occurring earthquakes and uncountable number of natural springs sprouting out from underneath the rocks of Himalayas is what makes this country a white-spot for earthquake research. Within the lengths of Nepal, sufficient data on pre-earthquake water quality changes may be obtained within a short period of time due to frequent occurrence of earthquakes of significant magnitudes. While it's not certain that what water quality parameters are likely to help in advancement of earthquake prediction science, multiple parameters can be monitored to detect precursory changes in groundwater. The larger number of parameters monitored higher is the chance of discovering the lucrative precursor of earthquake. In addition to this, studies on different types of geology are also crucial because the water quality parameter changes in one part of the world may not match with the changes in other part of the world. And it's very important to understand how one of the youngest and most seismically active systems gives away hints to an upcoming earthquake.

\subsection{Ground Water Quality Changes and Risk to Public Health}

In a country where direct groundwater is almost exclusively used for domestic purpose, including drinking, changes in quality of water may have severe effects on public health. Now that Nepal has suffered two major earthquakes and a long following series of aftershocks, underground water here has definitely undergone various physical and chemical alterations. According to research conducted in many other cases of major earthquakes, it's has been found that various chemical alterations in ground water takes place, some of which can create significant toxicity [5]. With high silicon content in Nepalese rocks, stress induced electrification of rocks $[4,3]$ cause to generate Hydrogen peroxide [12] and free hydroxyl radical and Toxic materials such as hydroxyl radicals 
that are formed prior to major earthquakes can help inactivate important enzymes required for biological functioning [2].

Due to inattention of concerned parties no assessment of groundwater quality changes has been administered in the post-earthquake scenario. In fact, existence of this phenomenon is not even realized by many. Earthquake induced groundwater changes can have harmful effect on public health $[14,10]$. While some of us are aware that groundwater has observed many chemical changes, we are oblivious of what kind of changes these are and what effects it can bring on consumers' health. We're not sure of whether or these changes are subtle and insignificant or significant and injurious. Considering the magnitude of earthquake and the series of aftershocks, it is highly likely that chemical properties of ground water has significantly changed and is going to cause several harms to public health, if not soon, then at least in the long term. Earthquake can be attributed to numerous types of diseases that include infectious and parasitic diseases, Neoplasms, Disease of the blood and blood forming organs Endocrine, nutritional and metabolic diseases, Mental and behavioural disorders, Diseases of the nervous system, Diseases of the respiratory system, Diseases of the skin and subcutaneous tissue, Diseases of the musculoskeletal system and connective tissue Diseases of the genitourinary system. Of these diseases several are caused by chemical changes in groundwater such as changes in ion concentration and increase in turbidity [10].

\section{Conclusion}

Installation of water quality monitoring systems along the length of Himalayas can provide useful information on pre and post earthquake water quality parameters changes. Information on these changes is crucial to public health safety as well as to the advancement in earthquake prediction science. For now, its urgency is for assessing possible risks in public health caused by recent earthquakes in the region, but in a long term these monitoring systems can provide data that can help us in finding our way to prediction of earthquake. Observation of abrupt changes in water quality certainly won't help in accurate prediction as of now but it certainly tells us that an earthquake is occurring soon. This level of information can be of great help for early preparations. For a country such as Nepal, where the terrains are so difficult that even rescue-specialized aircrafts such as Osprey loses its efficiency, early preparedness can do a lot to reduce the potential mishaps of earthquakes.

\section{References}

[1] Avouac JP, Meng L, Wei S, Wang T and Ampuero JP (2015), Lower edge of locked Main Himalayan Thrust unzipped by the 2015 Gorkha earthquake. Nature Geoscience, 8 : 708-711.

[2] Balka M, Boseb M, Ertemc G, Rogoffd DA, Rothschilda LJ and Freund FT (2009), Oxidation of water to hydrogen peroxide at the rock-water interface due to stress-activated electric currents in rocks. Earth and Planetary Science Letters, 283 : 87-92.

[3] Freund F (2002), Charge generation and propagation in igneous rocks. Journal of Geodynamics, $33: 543-570$.

[4] Freund F (2010), Toward a unified solid state theory for pre-earthquake signals. Acta Geophysica, $58: 719-766$.

[5] Grant RA, Halliday T, Balderer WP, Leuenberger F, Newcomer M, Cyr G and Freund FT (2011), Ground Water Chemistry Changes before Major Earthquakes and Possible Effects on Animals. International Journal of Environmental Research and Public Health, 8 : 1936-1956. 
[6] Igarashi G, Saeki S, Takahata N, Sumikawa K, Tasaka S, Sasaki Y, Takahashi M and Sano Y (1995), Ground-water radon anomaly before the kobe earthquake in Japan. Science, 269 : 60-61.

[7] Malakootian M and Nouri J (2010), Chemical Variations of Ground Water Affected by the Earthquake in bam region. International Journal of Environmental Research, 4 : 443-454.

[8] Molden D, Sharma E and Acharya G (2015), Lessons from Nepals's Gorkha Earthquake 2015. International Centre for Integrated Mountain Development (ICIMOD).

[9] Nepal Disaster Report. Edited by Dangal R (2015), Government of Nepal Ministry of Home Affairs.

[10] Shitov AV (2010), Health of people living in a seismically active region. In: Florinsky, I.V. (Ed.), Man and the Geosphere. Nova Science Publishers, New York, USA.

[11] Skelton A, Andrén M, Kristmannsdóttir H, Stockmann G, Mörth C-M, Sveinbjörnsdóttir Á, Jónsson S, Sturkell E, Guðrúnardóttir HR and Hjartarson H (2014), Changes in groundwater chemistry before two consecutive earthquakes in Iceland. Nature Geosciences, 7 : 752-756.

[12] Tsunogai U and Wakita H (1995), Precursory chemical changes in ground water: kobe earthquake, Japan. Science, 269 : 60-63.

[13] United States Geological Survey (2015), earthquake.usgs.gov.

[14] Wood H (2014), The Effects of Earthquakes on Groundwater in Santa Clara County. 